\title{
FACULTY POSITION IN ACTUARIAL SCIENCE
}

The School of Actuarial Science invites applications for two tenure-track professoral appointments starting August 1994. The School is reponsible for teaching and research in actuarial science and the two new professors will join the seven faculty members currently in function.

The duties of a professor include teaching to undergraduate and graduate students, conducting active research in actuarial science, counseling students, supervising graduate students, and participating to the academic responsibilities of the School.

For the first available position, the qualifications requested of a candidate are Hold (or be near completion of) a Ph. D. preferably in actuarial science or related area; be well engaged in actuarial research; be a member of (or a candidate for membership in) a recognized association of actuaries.

For the second vacant post, is also admissible

A Fellow of any recognized association of Actuaries or the equivalent who can prove research production in actuarial science and capacity for supervising graduate students.

Applications must be sent in writing to the following address with a recent curriculum vitae enclosed:

Mr. André Prémont, director

School of Actuarial Science

Alexandre-Vachon Building

Laval University

Sainte-Foy (Québec)

G1K 7P4

Laval University applies an equal opportunity program and dedicates half of its openings to women applicants. In accordance with Canadian immigration requirements, this advertisement is directed, in the first instance, to Canadian citizens and permanent residents. 